\title{
Blood Analysis of Growing Rabbits Fed Cooked Bambara Nut Meal as Replacement for Groundnut Cake in a Semi-Arid Zone of Nigeria
}

\author{
Usman, Y. ${ }^{1}$; Husa, H. ${ }^{2}$; Yusuf, S. Z. ${ }^{3}$; Bukar, B. S. ${ }^{4}$ D Dunya, A. M. ${ }^{5}$
}

\author{
${ }^{1}$ Dept. of Agric. Education, Kashim Ibrahim College of Education Maiduguri, Nigeria \\ ${ }^{2}$ Dept. of Animal Production Technology, Ramat Polytechnic Maiduguri, Nigeria \\ ${ }^{3}$ Dept. of Animal Science and Range Management, Modibbo Adama University of Technology, Yola, Nigeria \\ 4 Dept. of Immunology, University of Maiduguri Teaching Hospital, Maiduguri, Nigeria \\ 5 Dept. of Animal Science, Federal University of Gashua, Yobe State, Nigeria
}

\begin{abstract}
A ten-weeks feeding trial was conducted to determine the effect of replacing groundnut cake (GNC) with cooked Bambara nut meal (CBNM) on the Heamatology and serum biochemistry of Growing Rabbits. Thirty mixed breed (New Zealand White X Dutch) of rabbits six to seven weeks of age with initial body weight of $604.50 \mathrm{~g}$ were caged individually and allotted to 5 dietary treatments. Each treatment had six (6) replications. The diets and clean drinking water were given ad libitum throughout the period of experiment. In diets 1(control), 2, 3, 4 and 5 CBNM replaced GNC at 0\%, 25\%, 50\%, 75\% and 100\%, respectively. All data collected in the course of the experiment were subjected to analysis of variance (ANOVA) using the completely randomized design (Steel and Torrie,1980) and where applicable Duncan's multiple range test, was used for meanseparation. The haematological parameters indicated that there were no significant $(P>0.05)$ differences among treatment groups for $\mathrm{PCV}, \mathrm{RBC}, \mathrm{WBC}, \mathrm{MCV}, \mathrm{MCH}$ and $\mathrm{MCHC}$, while Hb differ significantly $(P<0.05)$ with animals on treatment $5(100 \% C B N M)$ having highest value of $12.73 \mathrm{~g} / \mathrm{dl}$ while animals on the control $(0 \% C B N M)$ had $11.10 \mathrm{~g} / \mathrm{dl}$ as the lowest. There were no significant differences $(P>0.05)$ among treatment groups in total protein, albumin, creatinine, urea, cholesterol and glucose. Globulin range of 4.67-11.00 g/l was obtained with significant difference $(P<0.05)$ among treatment groups with T3 $(50 \%$ CBNM) having higher value of $11.00 \mathrm{~g} / \mathrm{l}$ and T4 (75\%CBNM) having $4.67 \mathrm{~g} / \mathrm{l}$ the lowest. Serum electrolytes; Phosphorus (P), Calcium (Ca) and bicarbonate showed no significant $(P>0.05)$ difference among treatment groups.
\end{abstract}

Keywords-Heamatological, Biochemical, Growing Rabbits and Cooked Bambara Nut Meal.

\section{INTRODUCTION}

There is a widespread malnutrition in developing countries like Nigeria due to lack of animal protein consumption. The present state of the economy i.e recession coupled with current inflationary trend, scarcity and cost of production contribute to the poor production of animal protein which is required in high demand. FAO (1990), reported that out of the $44 \mathrm{~g}$ protein supply per caput, animal products constitute about 2\%, leading to malnutrition and under nutrition of all ages in Nigeria. To overcome the animal protein insufficiency, the need to improve on the feeding management and productive performance of livestock in Nigeria become imperative. This can be achieved by the introduction of the nontraditional meat sources such as rabbits for small scale farmers to rear for its meat and other by-products. Rabbit production and consumption in Nigeria as a livestock species is fast gaining importance and popularity in the semi-arid zone. The have a high feed conversion ratio and are efficient converters of plants products and seeds (Asuquo, 1997). The meat is richer in protein, certain vitamins and minerals, low in fats, and nutritious with high calorie value compared to meat of other species. The high cost of conventional feed ingredients as a result of competition between human and livestock brings about persistent shortfall of animal protein in the diets of most people living in developed countries, which invariably leads to undernourishment. The use of non-conventional feed such as Bambara groundnut to feed fast-growing animals like rabbit should be given attention. The study will serve as a step towards improving the nutritional status and economic well-being of peasant farmers in Maiduguri. 


\section{MATERIALS AND METHODS}

The feeding trial was conducted at the Ramat Polytechnic Teaching and Research, Maiduguri. Maiduguri is located within latitude $11^{0}$ 5'north and longitude $13^{\circ} 9^{\prime}$ east (Encarta, 2007). It has an altitude of $354 \mathrm{~m}$ above sea level (Alaku, 1983). The vegetative zone falls within the sahelian region of West Africa. The annual rainfall varies from 500-600mm with short duration of 3-4 months rainy season; long dry season of 7-8 months is prevalent. According to Ugherughe and Ekedolum (1986), the mean relative humidity ranges from $30 \%-50 \%$ around February to March, while maximum record of $90 \%$ is observed around August. Ambient temperatures are higher during the months of April to May and may reach up to $40^{\circ} \mathrm{C}$ and above (Alaku, 1983). According to Aliyu (2007), ambient temperature could be as low as $20^{\circ} \mathrm{C}$ during the cold season while during the hot period, which is between February to June, it can reach $44^{0} \mathrm{C}$.

\section{Method of Processing Bambara groundnut seeds}

The Bambara groundnut seeds were subjected to cooking at boiling point $\left(100^{\circ} \mathrm{C}\right)$ for a period of one hour in an aluminum cooking pot containing water sufficient enough to cover the seeds using firewood as a source of fuel. After cooking for the period of one hour, the seeds were separated from the water and sun-dried for five days. This is to ensure complete reduction of moisture for ease of milling as corroborated by Omoikhoje et al. (2005) and Omoikhoje et al. (2006). The sun-dried seeds were then milled and used for the preparation of the experimental diets.

\section{Experimental stock and management}

Thirty (30) mixed breed (New Zealand white X Dutch) of rabbits 6-7 weeks of age, were used for the feeding trial that lasted for the duration of ten (10) weeks, excluding one (1) week of adjustment period. The rabbits were weighed and randomly assigned to five (5) different dietary treatments, each treatment containing six (6) replicates. The rabbits were kept in separate cages made from wire with dimensions of $42 \mathrm{~cm} \mathrm{x} 42 \mathrm{~cm} \times 43 \mathrm{~cm}$ (LX $\mathrm{W} X \mathrm{H})$. Cages were raised above the ground level for ease of cleaning. Metallic feeding trough and plastic drinkers were provided in each cage. Water and feed were provided ad libitum throughout the period of experiment.

\section{Experimental diets}

Five (5) experimental diets were prepared in which cooked Bambara groundnut meal (CBGM) replaced groundnut cake (GNC) as a source of protein at $0 \%, 25 \%, 50 \%, 75 \%$ and $100 \%$ levels in diets $1,2,3,4$ and 5 respectively that produced is nitrogenous and is calorie diets formulated to contain $18 \%$ crude protein and 3437 metabolizable energy (kcal/kg).

\section{The parameters measured}

The parameters measured were haematological and biochemical characteristics. At the end of the $7^{\text {th }}$ week of the experiment, blood samples were collected from 3 rabbits per treatment for haematolgical investigation. Blood sample was collected via ear veins of sampled rabbits. Disposable syringe and needle of $20 \mathrm{~mm}$ gauges was used. The rabbits were fasted overnight (12 hours) and bled in the morning to collect blood. Fasting was to avoid temporary elevation of blood metabolites as a result of feeding (Bush, 1975). Sterilization of collection site was carried out using alcohol, while xylenes was applied to dilate the veins. After collection of blood samples, sterile cotton wool was applied to cover the pierced veins. Collected blood samples were emptied into bottles containing dipotassium salt of ethylene diamine tetraacetic acid. (EDTA-K ${ }^{2+}$ ) as anti-coagulant, while blood to be used for serum analysis were collected in separate bottles without anti-coagulant. The blood samples were analysed according to Bush (1975) in the Haematology Laboratory, University of Maiduguri Teaching Hospital (UMTH). Collected blood samples were emptied into plain bottles and allowed to stand for coagulation at room temperature. The samples were then centrifuged for ten minutes at 2,000 revolutions per minutes (rpm) to separate the cell from serum.The total protein, albumin and globulin in the serum were analysed using Sigma assay kits (Sigma Chemical Co. St. Louis, Missouri, USA). The total serum protein and serum albumin were determined by Biuret reactions (Bush, 1975). The total serum protein was first estimated and then performing fractionation on further volume of the sample to precipitate and remove globulins; this leaves only albumin in solution.The serum urea estimation was carried out by the Diacetly Monoxime (WHO, 1980). Here, the protein was first precipitated by trichloroacetic acid. The urea in the filtrate then reacted with diacetyl monoxime in the presence of acid, oxidizing reagent and thiosemicarbazide to give a coloured solution. This was then measured in a photoelectric colorimeter at a wavelength of $520 \mathrm{~nm}$.

Urea Concentration $(\mathrm{mmol} / \mathrm{l})=\underline{\mathrm{AT}} \times 100$

\section{AR}

Where:

$\mathrm{AT}=$ Absorbance of test sample

$\mathrm{AR}=$ Absorbance of reference sample

Serum Cholesterol was determined by colorimeteric enzyme method as outlined by Bush (1975). The method involves enzymatic hydrolysis and oxidation which terminates in the production of a red coloured solution. The concentration was determined after reading the colorimeter at $546 \mathrm{~nm}$. The serum glucose was estimated 
by orthotoliudine method as described in WHO (1980). In this method, protein was first precipitated by tricholoroacetic acid. The glucose in the filtrate reacted with orthotoluidine reagent to give a green colour; this was then measured in a photoelectric colorimeter at a wavelength of $630 \mathrm{~nm}$.

Concentration of glucose $=\underline{\mathrm{AT}} \times 200(\mathrm{mmol} / \mathrm{l})$

AR

Where:

$\mathrm{AT}=$ Absorbance of test sample

$\mathrm{AR}=$ Absorbance of reference sample

\section{Data collection}

All data collected in the course of the experiment were subjected to analysis of variance (ANOVA) using the randomized complete block design (Steel and Torrie, 1980) and where applicable, Duncan's multiple range test (Duncan, 1955) was used for mean separation.

\section{RESULTS AND DISCUSSION}

The haematological parameters are shown in Table 1. There were no significant $(\mathrm{P}>0.05)$ difference among the treatments in their packed cell volume which ranges between 35.33 and $41.00 \%$. The control group (0\%CBGM), however, has lower PCV of $35.33 \%$. The $\mathrm{PCV}$ range obtained in this study were within the normal range of $31 \%$ to $50 \%$ recommended by Canadian Council on Animal Care (1984) and closer to the range of $50 \%$ reported by Medirabbit (2003) as the ideal for healthy rabbits. Ehebha etal. (2008) reported PCV range of $32.50 \%$ to $39.69 \%$ when they fed CBGM to weaner rabbits and described it as adequate for growing rabbits receiving proper nourishment. There were significant differences $(\mathrm{P}<0.05)$ in the $\mathrm{Hb}$ values among rabbits receiving the various treatments diets. The range of $11.10 \mathrm{~g} / \mathrm{dl}$ to 12.73 $\mathrm{g} / \mathrm{dl}$ which was observed in this experiment is within the range of $9.40 \mathrm{~g} / \mathrm{dl}$ to $17.40 \mathrm{~g} / \mathrm{dl}$ reported in Medirabbit (2003) and closer to values of $10.50 \mathrm{~g} / \mathrm{dl}$ to $12.95 \mathrm{~g} / \mathrm{dl}$ obtained by Ehebha et al. (2008) who fed CBGM to growing rabbits. The values of $\mathrm{Hb}$ obtained in this study are within the normal range for adequate metabolism and as such there is no sign of aneamia in the rabbits. There were no significant differences $(\mathrm{P}>0.05)$ among the treatments in the RBC and WBC. The range for the RBC observed was 4.10-4.93 X $10^{6} \mu \mathrm{l}$ which is comparable to the values of 3.85-4.66 X $10^{6} \mu 1$ and 3.55-3.81 X $10^{6} \mu 1$ reported by Ehebha et al. (2008) and Omoikhoje et al. (2004) respectively for young rabbits. Therefore, the values obtained in this study could be considered as adequate for growing rabbits thus, indicating that the rabbits are in a good condition of health with normal functioning of body systems. The WBC range observed in this experiment was 7.23-8.27 $\mathrm{X} 10^{3} \mu 1$. There was no significant difference $(\mathrm{P}>0.05)$ among treatment groups and the range conformed with the value $\left(7.89 \times 10^{3} \mu \mathrm{l}\right)$ reported earlier by Schalm et al. (1975) and within the recommended range of 5 to $13 \times 10^{3} \mu 1$ in Medirabbit (2003). The values of WBC obtained indicated that the rabbits were in good health condition and in a state of readiness to combat attack by foreign bodies as indicated by Ehebha et al. (2008). There was no significant ( $\mathrm{P}>0.05$ )difference among treatment groups with respect to the MCV, MCH and MCHC. The MCV range of $66.10 \mathrm{fl}$ to $73.37 \mathrm{fl}$ compares favourably with the values of $50 \mathrm{fl}$ to $75 \mathrm{fl}$ reported in Medirabbit (2003) and $68.20 \mathrm{fl} \pm 4.10 \mathrm{fl}$ by Schalm et al. (1975). The MCH range of $20.33 \mathrm{Pg}$ to $24.27 \mathrm{Pg}$ and $\mathrm{MCHC}$ of $30.27 \%$ to $31.23 \%$ observed in this experiment were close to the values of 18 to $24 \mathrm{Pg}$ and $27 \%$ to $34 \%$ for MCV and MCHC respectively reported in Medirabbit (2003). Since there was no indication of anaemia among rabbits, the treatment diets are nutritionally adequate for growing rabbits and could support good health and normal growth. The following serum were investigated: total protein, albumin, globulin, creatinine, urea, glucose, calcium, phosphorus and bicarbonate. The results obtained for the biochemical indices are presented in Table 1 . There was no significant difference $(\mathrm{P}>0.05)$ among treatment groups in the total protein and albumin. Total protein value of $62.00 \mathrm{~g} / \mathrm{l}$ to $67.67 \mathrm{~g} / \mathrm{l}$ obtained were within the reference values of 50 $\mathrm{g} / 1$ to $75 \mathrm{~g} / \mathrm{l}$ reported in Medirabbit (2003). Albumin value range of $52.00 \mathrm{~g} / 1$ to $62.33 \mathrm{~g} / \mathrm{l}$ obtained was higher than the reference value of $25 \mathrm{~g} / \mathrm{l}$ to $40 \mathrm{~g} / \mathrm{l}$ reported in Medirabbit (2003) for albumin. However, high serum protein and high albumin values are indications of good protein quality according to Omoikhoje et al. (2004). There were significant difference $(\mathrm{P}<0.05)$ among treatment groups in the globulin values obtained. The globulin value of $4.67 \mathrm{~g} / 1$ to $11.00 \mathrm{~g} / \mathrm{l}$ were lower than values of $20.94 \mathrm{~g} / \mathrm{l}$ to $28.11 \mathrm{~g} / \mathrm{l}$ and that of $25 \mathrm{~g} / \mathrm{l}$ to $40 \mathrm{~g} / \mathrm{l}$ reported by Ehebha et al. (2008) and Medirabbit (2003) respectively. However, low globulin could be due to high albumin as the two are inversely related. There were no significant differences ( $>0.05$ ) among treatments groups in the values of creatinine recorded. The values of 98.67-121.67 $\mu \mathrm{mol} / \mathrm{l}$ observed for creatinine were within the range of 53124( $\mu \mathrm{mol} / \mathrm{l})$ reported in Medirabbit (2003). The values for urea recorded $(3.20 \mathrm{mmol} / 1$ to $8.03 \mathrm{mmol} / \mathrm{l})$ were lower than $9.1 \mathrm{mmol} / 1$ to $25.5 \mathrm{mmol} / 1$ reported in Medirabbit (2003) but closer to the values of $4.20 \mathrm{mmol} / \mathrm{l}$ to 6.80 mmol/l reported by Archetti et al. (2008). The values of the urea and other indices such as cholesterol, glucose and serum electrolytes (phosphorus, calcium and bicarbonate) 
were similar in all the treatments. The cholesterol values of $2.23 \mathrm{mmol} / \mathrm{l}$ to $5.27 \mathrm{mmol} / \mathrm{l}$ were higher than $0.10 \mathrm{mmol} / \mathrm{l}$ to $2.00 \mathrm{mmol} / \mathrm{l}$ reported in Medirabbit (2003). The higher cholesterol could be due to higher fat content of Bambara nut as indicated by proximate analysis $(8.13 \%)$ which was closer to the values of $7.15 \%$ and $8.31 \%$ for raw and roasted Bambara nut reported by Akande et.al. (2009). Omoikhoje et al. (2004) had earlier explained that cooked Bambara groundnut meal does not contain cholesterol levels that can pose health hazard. The glucose ranges of 5.80 to $7.00(\mathrm{mmol} / \mathrm{l})$ were within the range of 4.20 to 8.90 (mmol/l) reported in Medirabbit (2003) as normal for growing rabbits. The serum electrolytes (phosphorus, calcium and bicarbonate) had ranges of 2.4 . $\mathrm{mmol} / 1$ to 2.56 $\mathrm{mmol} / \mathrm{l}, 0.73 \mathrm{mmol} / \mathrm{l}$ to $0.96 \mathrm{mmol} / \mathrm{l}$ and $20.67 \mathrm{mmol} / 1$ to $21.33 \mathrm{mmol} / 1$ respectively in this experiment. This is an indication that the nerve functions and nerve disposition of the animals are normal.

\section{CONCLUSION AND RECOMMENDATION}

The continued increase in the demand for animal protein in the diet of people living in developing countries calls for an increase in production of fast-growing and prolific animals such as rabbit using non-conventional feed ingredients like Bambara groundnut.
In this study cooked Bambara groundnut meal was found to be suitable for the feeding of growing rabbits at different levels of inclusions, from $25 \%$ to $100 \%$ as a replacement for groundnut cake, a conventional plant protein source. Rabbits fed varied levels of CBGM have shown good performance in terms of weight gain, feed efficiency and nutrient digestibility. The diet was also found to have no deleterious effects on growing rabbits as revealed by the haematological and serum biochemical indices of the rabbits fed the various diets. Although CBGM can replace $100 \%$ of the GNC in the rabbit's diets, the inclusion of up to $50 \%$ of CBGM in the diet of growing rabbits as replacement for GNC gave optimum economic benefits. The use of CBGM in the feeding of growing rabbits is a simple and cheaper method of overcoming the adverse effects of the anti-nutritional factors. From this experiment it can be concluded that cooked Bambara groundnut meal (CBGM) can replace groundnut cake (GNC) at different levels of inclusions but $50 \%$ CBGM diets should be used for optimum economic benefit. However, to obtain more information, it is recommended that investigations be extended to cover other age groups and classes of rabbits such as fattening, pregnant and lactating rabbits.

Table1: Hematological indices of rabbits fed varied levels of cooked bambara groundnut meal (CBGM) as replacement for groundnut cake $(G N C)$

\begin{tabular}{|c|c|c|c|c|c|c|}
\hline \multicolumn{7}{|c|}{ Levels of GNC replaced by CBGM } \\
\hline Parameters & $\mathrm{T} 1(0 \%)$ & $\mathrm{T} 2(25 \%)$ & $\mathrm{T} 3(50 \%)$ & $\mathrm{T} 4(75 \%)$ & T5 $(100 \%)$ & SEM \\
\hline $\begin{array}{l}\text { Packed cell } \\
\text { volume }(\%)\end{array}$ & 35.33 & 41.00 & 38.00 & 38.00 & 41.00 & $0.0137^{\mathrm{NS}}$ \\
\hline $\begin{array}{l}\text { Haemoglobin } \\
\text { concentration }(\mathrm{g} / \mathrm{dl})\end{array}$ & $11.10^{\mathrm{c}}$ & $12.43^{b c}$ & $11.63^{\mathrm{ab}}$ & $11.80^{\mathrm{ab}}$ & $12.73^{\mathrm{a}}$ & $0.2689 *$ \\
\hline $\begin{array}{l}\text { Red blood cells } \\
\left(\mathrm{x} 10^{6} \mu \mathrm{l}\right)\end{array}$ & 4.20 & 4.13 & 4.93 & 4.27 & 4.10 & $0.2994^{\mathrm{NS}}$ \\
\hline $\begin{array}{l}\text { White blood cells } \\
\left(\mathrm{x} 10^{3} \mu \mathrm{l}\right)\end{array}$ & 8.10 & 7.23 & 7.53 & 8.27 & 7.50 & $1.3019^{\mathrm{NS}}$ \\
\hline $\begin{array}{l}\text { Mean corpuscular } \\
\text { volume (fl) }\end{array}$ & 73.37 & 66.10 & 70.77 & 69.53 & 72.30 & 4.0849 NS \\
\hline $\begin{array}{l}\text { Mean corpuscular } \\
\text { haemoglobin (pg) } \\
\text { Mean corpuscular } \\
\text { haemoglobin } \\
\text { conc. } \quad(\%)\end{array}$ & 24.27 & 20.33 & 21.87 & 21.63 & 22.60 & $1.2599^{\mathrm{NS}}$ \\
\hline
\end{tabular}

$\mathrm{SEM}=$ standard error of means

$\mathrm{NS}=$ not significant $(\mathrm{P}>0.05)$

* = Significant difference $(\mathrm{P}>0.05)$ 
$\mathrm{a}, \mathrm{b}, \mathrm{c} .=$ means in the same row bearing different superscripts differ significantly $(\mathrm{P}<0.05)$.

Table 2: Serum biochemical indices of rabbits fed varied levels of cooked Bambara groundnut meal (CGBM) as replacement for groundnut cake $(G N C)$

\begin{tabular}{|c|c|c|c|c|c|c|}
\hline \multirow[b]{2}{*}{ Parameters } & \multicolumn{5}{|c|}{ Levels of GNC replaced by CBGM } & \multirow[b]{2}{*}{ SEM } \\
\hline & $\mathrm{T} 1(0 \%)$ & $\mathrm{T} 2(25 \%)$ & $\mathrm{T} 3(50 \%)$ & $\mathrm{T} 4(75 \%)$ & T5 $(100 \%)$ & \\
\hline Total protein $(\mathrm{g} / \mathrm{l})$ & 62.33 & 67.67 & 65.33 & 62.00 & 68.00 & $3.0614^{\mathrm{NS}}$ \\
\hline Albumin $\quad(g / l)$ & 52.00 & 57.33 & 54.33 & 57.33 & 62.33 & $3.1894^{\mathrm{NS}}$ \\
\hline Globulin $\quad(g / 1)$ & $10.33^{\mathrm{b}}$ & $10.34^{\mathrm{b}}$ & $11.00^{\mathrm{a}}$ & $4.67^{\mathrm{c}}$ & $5.67^{\mathrm{c}}$ & $1.0775^{*}$ \\
\hline Creatinine $(\mu \mathrm{mol} / \mathrm{l})$ & 121.67 & 118.00 & 115.33 & 98.67 & 108.33 & $12.212^{\mathrm{NS}}$ \\
\hline$(\mathrm{mmol} / \mathrm{l})$ & 5.93 & 8.03 & 3.20 & 7.00 & 6.13 & $0.6559^{\mathrm{NS}}$ \\
\hline Cholesterol(mmol/l) & $3.57^{\mathrm{ab}}$ & $3.20^{\mathrm{ab}}$ & $5.27^{\mathrm{a}}$ & $4.53^{\mathrm{ab}}$ & $2.23^{\mathrm{b}}$ & $0.7464^{*}$ \\
\hline Glucose $\quad(\mathrm{mmol} / \mathrm{l})$ & 5.80 & 6.01 & 7.00 & 6.20 & 5.83 & $0.3889^{\mathrm{NS}}$ \\
\hline Calcium (mmol/l) & 2.56 & 2.50 & 2.40 & 2.40 & 2.50 & $0.0830^{\mathrm{NS}}$ \\
\hline Phosphate (mmol/l) & 0.73 & 0.96 & 0.76 & 0.90 & 0.80 & $0.1160^{\mathrm{NS}}$ \\
\hline Bicarbonate $(\mathrm{mmol} / \mathrm{l})$ & 20.67 & 21.33 & 20.67 & 21.00 & 20.00 & $0.5055^{\mathrm{NS}}$ \\
\hline
\end{tabular}

SEM $=$ standard error of means

$\mathrm{NS}=$ not significant $(\mathrm{P}>0.05)$

* $\quad$ Significant difference $(\mathrm{P}>0.05)$

$\mathrm{a}, \mathrm{b}, \mathrm{c}=$ means in the same row bearing different superscripts differ significantly $(\mathrm{P}<0.05)$.

\section{REFERENCES}

[1] Akande, K.E., Abubakar, M.M., Adegbola, T.A., Bogoro, S.E., Doma, U.D. and Fabiyi, E.F. (2009). Nutrient composition and uses of Bambara groundnut (Voandzeiasubsterranea (L) VERDCOURT). Continental. J. Food Sci. Technol. 3:8-13. Wilolud online journals, 2009.

[2] Alaku, S.O. (1983). Body and carcass losses in goats during the advance period of West Africa Sahelian dry season. Wld. Rev. Anim. Prod. 19: 49-54.

[3] Aliyu, J. (2007). Assessment of the productivity in the four strains of indigenous chickens in a semi-arid region of North-eastern Nigeria. Unpublished Ph.D. Thesis, proposal. Department of Animal Science, University of Maiduguri, Maiduguri.

[4] Archetti, I., Tittarelli, C., Ceioli, M., Brivio, R., Grilli, G. and Lavazza, A. (2008).Serum chemistry and haematology values in commercial rabbits: Preliminary data from industrial farms in Northern Italy. $9^{\text {th }}$ World Rabbit Congress. June 10-13. Verona. Italy.

[5] Asuquo, B.O. (1997). Nigeria journal of Animal production24 (1): 46-50

[6] Bush, B.M. (1975). Veterinary laboratory Manual. William Heinemann Medical Books Ltd. London. 442p.

[7] Canadian Council on Animal Care (1984). Guide to care and use of pets and laboratory experimental animals. 1:8586.

[8] Duncan, D.B. (1955). Multiple range and multiple F-tests. Biometrics 11: 1- 42.

[9] Ehebha, T.E., Omoikhoje, S.O., Bamgbose, A.M., Aruna, M.B. and Isidhahomen, C.E. (2008). Haematology and serum chemistry of weaner rabbits fed cooked Bambara groundnut meal as replacement for soya bean meal. Proc.

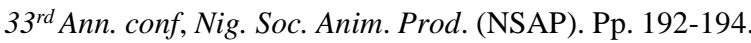

[10] Encarta. (2007). Encarta kids. Encyclopedia by Microsoft incorporations. USA.

[11] Medirabbit.com (2003). Complete blood count and biochemistry reference values in rabbits. Accessed online at www.medirabbit.com on 19/2/2011.

[12] Omoikhoje, S.O., Bamgbose, A.M., Oboh, S.O. and Eghiaruwa, B. (2004). Replacement value of groundnut cake with Bambara groundnut on the haematological traits and serum biochemistry of broilers. Proc. $9^{\text {th }}$ Ann. Conf. Anim. Sci. Ass. Nig. (ASAN).13 $13^{\text {th }}-16^{\text {th }}$ Sept. 2006. Abakaliki, Nigeria Pp. 86-89.

[13] Omoikhoje, S.O., Bamgbose, A.M., Aruna, M.B. and Uwagbale, A.A. (2005). Response of starter broiler fed graded levels of cooked Bambara groundnut meal. Proc. $39^{\text {th }}$ conf. Agric. Soc. Nig., University of Bennin, Benin Pp. 120-121

[14] Omoikhoje, S.O., Bamgbose, A.M.and Aruna, M.B. (2006). Growth response and cost benefit of broiler finisher fed diets containing different levels of cooked Bambara groundnut meal. Proc.11 $11^{\text {th }}$ Ann. Conf. Anim .Sci. Ass. Nig. (ASAN).Sept. $18^{\text {th }}-21^{\text {st }}$ I.A.R \& T. Ibadan, Nigeria. Pp. 158-159.

[15] Schalm, O.W., Jain, N.C. and Carrol, E. (1975). Veterinary Haematology $3^{\text {rd }}$ ed. Lea and Febiger Publishers, Philadelphia, USA. Pp. 160-210.

[16] Steel, R.G.D. and Torrie, J.H. (1980).Principles and Procedures of Statistics:A biometrical approach. $2^{\text {nd }}$ ed. McGraw Hill Book Co. New York, USA.

[17] Ugherughe, P.O. and Ekedolum, P.A. (1986). Pasture and rangeland potentials of Borno. Annals of Borno 3: 179-192.

[18] WHO. (1980). Manual of Basic Techniques for a Health Laboratory. World Health Organization, Geneva, Switzerland Pp. 75-43 